\title{
Constitutive Modulation of Raf-1 Protein Kinase is Associated with Differential Gene Expression of Several Known and Unknown Genes
}

\author{
Sonal Patel,* Fuh-Han Wang,* Theresa L. Whiteside,** and \\ Usha Kasid*† \\ Departments of ${ }^{*}$ Radiation Medicine and ${ }^{\dagger}$ Biochemistry and \\ Molecular Biology, Lombardi Cancer Center, Georgetown University, \\ Washington, D.C., U.S.A. \\ **Department of Pathology, Pittsburgh Cancer Institute, University of \\ Pittsburgh, Pittsburgh, Pennsylvania, U.S.A.
}

\begin{abstract}
Background: Raf-1, a cytoplasmic serine/threonine protein kinase, plays an important role in mitogen- and damage-responsive cellular signal transduction pathways. Consistent with this notion is the fact that constitutive modulation of expression and/or activity of Raf-1 protein kinase modifies cell growth, proliferation, and cell survival. Although these effects are controlled at least in part by transcriptional mechanisms, the role of Raf- 1 in the regulation of specific gene expression is unclear. Materials and Methods: Differential display of mRNA was used to identify the genes differentially expressed in human head and neck squamous carcinoma cells (PCI06A) transfected with either the antisense c-raf-1 cDNA (PCI-06A-Raf(AS)), or a portion of CDNA coding for the kinase domain of Raf-1 (PCI-06A-Raf(K)). The differentially expressed fragments were cloned and sequenced, and they were used as probes to compare the expression patterns in parent transfectants by Northern blot analysis. In addition, expression patterns of the novel genes were examined in normal tissues and cancer cell lines. Results: Six differentially expressed cDNA fragments were identified and sequenced. Northern blot analysis revealed that four of these fragments representing human $\alpha 1$-antichymotrypsin ( $\alpha \mathrm{l}$-ACT), mitochondrial cytochrome c oxidase subunit II (COX-II), and two as-yet unidentified cDNAs (KAS-110 and KAS-111) were rel-
\end{abstract}

atively overexpressed in PCI-06A-Raf(AS) transfectants compared with PCI-06A-Raf(K) transfectants. The other two cDNA fragments representing human elongation factor- $1 \alpha(\mathrm{HEF}-1 \alpha)$ and ornithine decarboxylase antizyme (OAz) were overexpressed in PCI-06A-Raf(K) transfectants compared with PCI-06A-Raf(AS) transfectants. The KAS-110 (114 bp) and KAS-111 (202 bp) cDNAs did not show significant matches with sequences in the GenEMBL, TIGR, and HGS DNA databases, and these may represent novel genes. The KAS-110 and KAS-111 transcripts, $\sim 0.9 \mathrm{~kb}$ and $\sim 0.5 \mathrm{~kb}$, were observed in most normal tissues and several cancer cell types, indicating their housekeeping function.

Conclusions: This study reports novel components of the Raf- 1 signaling pathway. $\alpha 1-\mathrm{ACT}, \mathrm{HEF}-\mathrm{l} \alpha$, COX-II, and $\mathrm{OAz}$ have been previously implicated in diverse cellular responses including transformation, energy metabolism, and cell survival. Our data suggest that expression of these genes may play a role in the Raf-1-mediated biological activity of PCI-06A cells. The KAS-110 and KAS- 111 cDNAs represent unknown genes, and further investigations are necessary to determine their role in the cellular response. Identification of specific targets may provide useful markers for prognosis and therapy selection in squamous cell carcinoma.

\section{INTRODUCTION}

Raf- 1 , the product of the proto-oncogene c-raf- 1 , is a cytoplasmic $70-75 \mathrm{kDa}$ serine/threonine

Address correspondence and reprint requests to: Dr. Usha Kasid, E208, Research Bldg., Lombardi Cancer Center, Georgetown University, 3970 Reservoir Road, N.W., Washington, D.C. 20007, U.S.A. Phone: 202-687-2226; Fax: 202687-0400; e-mail: Kasidu@gunet.georgetown.edu protein kinase. A variety of biochemical experiments have shown that Raf-1 protein kinase is an important component of the signal transduction pathways initiated by diverse agents, including growth factors, cytokines, ultraviolet radiation, and ionizing radiation (1-8). In addition, we and others have shown that the constitutive activation of Raf-1 protein kinase occurs by trun- 
cation of the regulatory amino terminus and retention of the kinase domain $(9-12)$. Activated Raf- 1 triggers a kinase cascade that includes the phosphorylation of the mitogen-activated extracellular kinase (MEK), a dual-specificity kinase that stimulates the mitogen-activated protein kinase, MAPK (13). Of further importance are observations that activated Raf- 1 transactivates transcription from the following sites: AP-1 and Ets binding sites in the polyoma virus enhancer, c-fos and egr-1 promoters, and promoter containing NF- $\kappa$ B binding site $(5,14-16)$. The role of Raf- 1 in the regulation of specific gene expression is unclear.

Depending on the cell type, the constitutive modulation of expression and/or activity of Raf-1 leads to various biological consequences. For example, the catalytic activation of Raf-1 protein kinase is associated with the neoplastic growth of recipient fibroblasts and epithelial cells (9-12). We have reported a correlation of the inhibition of c-raf- 1 gene expression by antisense c-raf-1 cDNA transfection with delayed tumour growth in athymic mice and enhanced sensitivity to ionizing radiation in radioresistant head and neck squamous carcinoma cells (HNSCC, SQ20B) (17). Other studies have shown that inhibition of Raf-1 expression by antisense raf oligodeoxynucleotides has anti-tumor and radiosensitizing effects in different tumor cell types (18-20). A kinase-activated Raf-1 deletion mutant has been shown to improve Bcl-2 mediated resistance to apoptosis, and this requires targeting of Raf- 1 to mitochondrial membranes (21). Furthermore, mouse embryos with a targeted disruption of the c-raf-1 gene have been generated and display a phenotype strikingly similar to that of the epidermal growth factor (EGF) receptor knock-out mice, involving epithelial and placental defects (L. Wojnowski, personal communication). These diverse effects may be at least in part due to the involvement of Raf- 1 in the modulation of multiple effectors, each having a more direct role in the specific biological response.

The power of the differential display of mRNA technology to identify the differentially expressed genes remains undisputed (22). It allows the analysis of changes in specific mRNA levels by rapid display and simultaneous expression of mRNAs in the well-matched cell populations $(22,23)$. The purpose of this study was to identify the differentially expressed genes in the two isogeneic, transfectant cell lines established from the same human head and neck squamous carcinoma cell line (PCI-06A). PCI-06A-Raf(AS) transfectants were established by stable transfection of expression vector (pcDNA3) containing the full-length human antisense c-raf-1 cDNA into PCI-06A cells, and PCI-06A-Raf(K) transfectants were established by stable transfection of pcDNA3 plasmid DNA containing a kinase-activated deletion mutant of c-raf-1 cDNA into PCI06A cells (12). PCI-06A-Raf(AS) transfectants have flattened, epithelioid morphology, whereas PCI-06A-Raf(K) transfectants exhibit a strikingly transformed morphology consisting of spindleshaped and refractile cells showing anchorageindependent growth (12). We hypothesize that phenotypic differences in these two transfectants may be attributed to the differential expression of specific genes after constitutive modification of Raf-1. Identification of these effectors may provide important targets for prognosis and therapy selection in HNSCC.

\section{MATERIALS AND METHODS}

\section{Cell Culture}

Human tumor cells transfected with expression vector (pcDNA3) containing the entire coding domain of human c-raf-1 cDNA in the antisense orientation (PCI-06A-Raf (AS)) or a portion of cDNA coding for the kinase domain of Raf-1 (PCI-06A-Raf (K)) were established from a head and neck squamous carcinoma cell line (PCI06A) (24) as described earlier (12). PCI-06A-Raf (AS) and PCI-06A-Raf (K) transfectants were grown in minimum essential medium supplemented with $15 \%$ heat-inactivated fetal bovine serum (FBS), $10 \mathrm{mM}$ Hepes, $1 \mathrm{mM}$ nonessential amino acids, $2 \mathrm{mM}$ L-glutamine, $25 \mu \mathrm{g} / \mathrm{ml}$ gentamicin, $700 \mu \mathrm{g} / \mathrm{ml}$ G418, all obtained from Gibco/BRL (Grand Island, New York), and 0.4 $\mu \mathrm{g} / \mathrm{ml}$ hydrocortisone (Sigma, St. Louis, MO). Cells were cultured at $37^{\circ} \mathrm{C}$ under $5 \% \mathrm{CO}_{2}$.

\section{cDNA Synthesis and Differential Display of mRNAs (DD-RTPCR)}

Total cellular RNA was extracted from the PCI06A Raf (AS)/Raf (K) transfectants using guanidium isothiocyanate followed by the cesium chloride gradient centrifugation method (25). The RNA was then further cleaned of chromosomal DNA contamination by treating with DNAseI using the MessageClean kit according to the manufacturer's instructions (GenHunter, Brookline, MA). In the presence of $0.2 \mu \mathrm{m}$ of an anchor primer $\left(\mathrm{HT}-{ }_{11} \mathrm{~A}, \mathrm{HT}-{ }_{11} \mathrm{C}\right.$, or HT- ${ }_{11} \mathrm{G}$; Gen- 
Hunter) and $200 \mathrm{U}$ of Superscript II (Gibco/BRL) $0.5 \mu \mathrm{g}$ RNA was used in a reverse transcription reaction (RT) according to the manufacturer's instructions (GenHunter). cDNA was then either stored at $-20^{\circ} \mathrm{C}$ or used in a polymerase chain reaction (PCR). PCR was carried out according to the RNAimage kit (GenHunter). Briefly, $2 \mu \mathrm{l}$ of the RT mix was used in a reaction with $0.2 \mu \mathrm{M}$ of the same anchor primer as used in the cDNA generation and $0.2 \mu \mathrm{M}$ of an arbitrary primer (H-APl-H-AP8; GenHunter), $2 \mu \mathrm{M}$ dNTP, $10 \mu \mathrm{Ci}$ ${ }^{35} \mathrm{~S}$-dATP $(1250 \mathrm{Ci} / \mathrm{mmol}$; NEN Dupont, Boston, $\mathrm{MA}$ ) and 1 unit of Amplitaq (Perkin Elmer, Branchburg, NJ). The reactions were subjected to 40 cycles at $94^{\circ} \mathrm{C}$ for $30 \mathrm{sec}, 40^{\circ} \mathrm{C}$ for $2 \mathrm{~min}$, and $72^{\circ} \mathrm{C}$ for $30 \mathrm{sec}$, followed by a final soak temperature of $72^{\circ} \mathrm{C}$ for 5 min on the 9600 Perkin Elmer thermal cycler (Perkin Elmer). The reactions were then stored at $-20^{\circ} \mathrm{C}$. To examine the differentially displayed mRNAs, $3.5 \mu$ l of sample was mixed with $2 \mu \mathrm{l}$ of loading dye (GenHunter), incubated at $80^{\circ} \mathrm{C}$ for $2 \mathrm{~min}$, and electrophoresed on a $6 \%$ denaturing polyacrylamide gel, followed by autoradiography.

\section{Reamplification and Cloning of cDNA Fragments}

Bands of interest, bands overexpressed in the PCI-06A-Raf (AS) transfectants as compared to PCI-06A-Raf (K) transfectants or the converse, were located on the differential display gel and cut out, and DNA was eluted by soaking the bands in $20 \mu \mathrm{H}_{2} \mathrm{O}$ for $10 \mathrm{~min}$ and then boiling for $15 \mathrm{~min}$. The supernatant was ethanol precipitated and then sample was dissolved in $12 \mu \mathrm{l}$ $\mathrm{H}_{2} \mathrm{O}$ and reamplified using the original combination of the arbitrary and anchor primers according to the instructions in the RNAimage kit. If the amplified product was not detectable by $1.5 \%$ agarose gel electrophoresis, a third-step PCR as described above was carried out using a 1:10 dilution of the reamplified PCR product. The PCR product was cloned into the PCR 2.1 cloning vector according to the TA cloning kit instructions (Invitrogen, San Diego, CA). Plasmid DNA isolation from overnight cultures of the transformed E.coli cells (One Shot, INV $\alpha \mathrm{F}^{\prime}$; Invitrogen) was carried out by the alkaline lysis and phenol/chloroform extraction method (25). Size of the insert cDNA was determined by restriction digestion with EcoRI, followed by agarose gel electrophoresis. Inserts of expected sizes were purified from the agarose gel according to the Qiax II kit (Qiagen, Chatsworth, CA).

\section{cDNA Sequencing}

The partial cDNA clones representing differentially expressed mRNAs were sequenced in both directions, using either the T7 or M13 reverse primer (Stratagene, La Jolla, CA) and the Sequenase version 2.0 kit (Amersham, Cleveland, $\mathrm{OH}$ ) according to the manufacturer's instructions. DNA sequence was confirmed using the automated DNA sequencer (Applied Biosystems, Perkin Elmer). The cDNA sequences were subsequently entered in the DNA databases (GenEMBL, TIGR, HGS) to examine the homology to the known genes and available cDNAs.

\section{Northern Blot Hybridization Analysis}

Total RNA extracted from the transfectants was fractionated on a $1.0 \%$ formaldehyde agarose gel and transferred onto nitrocellulose membrane (Schleicher \& Schuell, Keene, OH). cDNA inserts and GAPDH CDNA probe were radiolabeled with ${ }^{32} \mathrm{P}$-dCTP using a random primer DNA labeling kit (Pharmacia Biotech, Piscataway, NJ). Blots were sequentially hybridized first to a radiolabeled partial human cDNA insert and then to GAPDH cDNA probe at $42^{\circ} \mathrm{C}$ in buffer containing $50 \%$ formamide, $5 \times$ SSC, $1 \times$ Denhardt's solution, $20 \mathrm{mM}$ sodium phosphate ( $\mathrm{pH} 6.8)$, and $200 \mu \mathrm{g} / \mathrm{ml}$ sheared and denatured salmon sperm DNA. Blots were washed three times in $2 \times \mathrm{SSC}$ and $0.1 \%$ SDS, five times in $0.2 \times$ SSC and $0.1 \%$ SDS, and twice in $2 \times \mathrm{SSC}$ at $55^{\circ} \mathrm{C}$. Dried blots were exposed to $\mathrm{X}$-ray films. Autoradiographs were computer-scanned using the Image-Quant software (Molecular Dynamics, Sunnyvale, CA). The statistical significance of the differences in gene expression between the two transfectants was determined using the paired $t$-test (Excel version 5.0). Expression of some of the cDNA fragments was also examined on $2 \mu \mathrm{g}$ per lane poly $(\mathrm{A})^{+}$mRNA blots of multiple human tissue and cancer cell lines (Clontech, Palo Alto, CA). These blots were sequentially hybridized with the cDNA insert followed by the $\beta$-actin cDNA probe according to the manufacturer's instructions. Briefly, prehybridization and hybridization were carried out in ExpressHyb solution (Clontech) at $68^{\circ} \mathrm{C}$. After washing, damp blots were covered with plastic wrap and exposed to X-ray film at $-70^{\circ} \mathrm{C}$. 


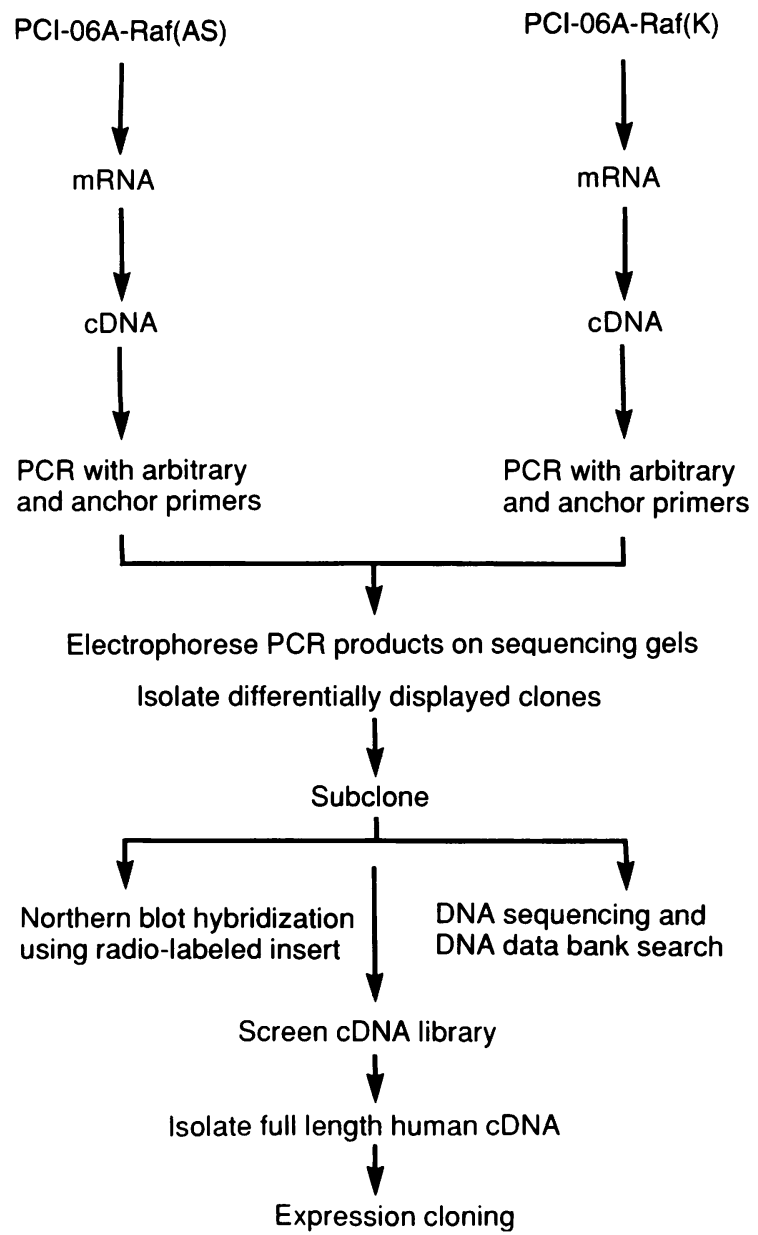

FIG. 1. Outline of experimental approach used for identification of differentially expressed transcripts in PCI-06A-Raf(AS) versus those in PCI-06A-Raf(K) transfectants

\section{RESULTS}

\section{Selection of Differentially Displayed mRNAs in PCI-06A-Raf(AS) versus PCI-06A-Raf(K) Transfectants}

The experimental approach used to identify the differentially expressed genes following the constitutive modulation of Raf- 1 protein kinase is outlined in Figure 1. We compared the patterns of differentially displayed mRNAs simultaneously in PCI-06A-Raf(AS) and PCI-06A$\operatorname{Raf}(\mathrm{K})$ transfectants. Twenty-four different anchor and arbitrary primer combinations were tested to identify differentially displayed mRNAs in these two categories. The overall patterns of the amplified cDNA species were essentially the same and any specific differences within the transfectant cell lines were easily visually identi- fiable. Each primer combination displayed approximately 150-200 bands, each band theoretically representing one transcribed gene (22). The selection of a differentially expressed band was based on the presence of this band in PCI06A-Raf $(\mathrm{K})$ transfectants and its absence in PCI06A-Raf(AS) transfectants or the converse, i.e., the presence of a band in PCI-06A-Raf(AS) transfectants and its absence in the PCI-06A-Raf (K) transfectants. If a band was present in both transfectant cell lines, selection was based on a significant visual difference in the band intensity noted in these two transfectant cell lines. In the present study, 6 of the 24 primer combinations used led to the identification of differentially expressed mRNAs: KAS-101, KAS-102, KAS-103, KAS-104, KAS-110, and KAS-111 (Table 1, Fig. 2). KAS-101, KAS-104, and KAS-110 fragments were selected on the basis of the relatively higher band intensity in PCI-06A-Raf(AS) cells, whereas KAS-102, KAS-103, and KAS-111 fragments were selected because of the relatively higher signal in PCI-06A-Raf(K) cells (Fig. 2). The selected fragments were eluted from the gels, purified, and reamplified. Each fragment exhibited single band upon reamplification (data not shown). The cDNA fragments were then cloned into the TA cloning vector.

\section{Identification of Differentially Displayed mRNAs}

Nucleotide sequencing analysis and GenEMBL DNA database homology search of the partial cDNA fragments were performed; the data are shown in Table 2. KAS-101 was found to have $96 \%$ sequence homology in 501 bp overlap to human $\alpha 1$-antichymotrypsin ( $\alpha$ l-ACT), KAS-102 had $98 \%$ homology in 309 bp overlap to human elongation factor-1 $\alpha$ (HEF- $1 \alpha$ ), KAS-103 had $99 \%$ homology in 160 bp overlap to human mitochondrial cytochrome c oxidase subunit II (COX-II), and KAS- 104 had $87 \%$ homology in 269 bp overlap to human ornithine decarboxylase antizyme (OAz). The partial cDNA sequences of two other fragments, KAS-110 (114 bp) and KAS-111(202 bp), showed no significant homology to any of the sequences in the GenEMBL database or to human cDNA sequences in the TIGR and HGS databases, indicating that these two CDNAs may represent the novel genes (Table 2, Fig. 3). 
TABLE 1. Sizes of differentially displayed fragments in PCI-06A-Raf (AS) versus PCI-06A-Raf (K) transfectants

\begin{tabular}{lccc}
\hline \multirow{2}{*}{$\begin{array}{l}\text { Differentially Displayed } \\
\text { Fragment }\end{array}$} & \multicolumn{2}{c}{ Primer Combination Used } & $\begin{array}{c}\text { Approximate Size } \\
\text { of Amplified } \\
\text { Product (bp) }^{c}\end{array}$ \\
\cline { 2 - 4 } KAS-101 & Arbitrary Primer & Anchor Primer $^{\boldsymbol{b}}$ & 950 \\
KAS-102 & AP4 & HT- ${ }_{11} \mathrm{C}$ & 350 \\
KAS-103 & AP5 & HT- ${ }_{11} \mathrm{C}$ & 200 \\
KAS-104 & AP2 & HT- ${ }_{11} \mathrm{C}$ & 300 \\
KAS-110 & AP6 & HT- ${ }_{11} \mathrm{C}$ & 200 \\
KAS-111 & AP2 & HT- ${ }_{11} \mathrm{G}$ & 200 \\
\hline
\end{tabular}

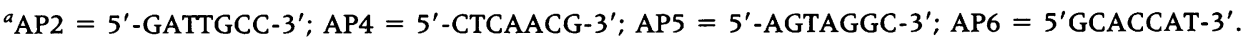

${ }^{b} \mathrm{H}=5^{\prime}$-AAGCTT-3'.

'Size of the amplified PCR products was determined by $1.5 \%$ agarose gel electrophoresis.

\section{Differential Expression of $\alpha 1-A C T$, HEF- $1 \alpha$, COX-II, and OAz Genes Following Constitutive Modulation of Raf-1}

When Northern blots of PCI-06A-Raf(AS) and PCI-06A-Raf(K) transfectants were hybridized with the radiolabeled partial cDNA inserts (KAS101 to KAS-104, Table 2), the expected sizes of the corresponding known transcripts were observed in both transfectants (Fig. 4). Consistent with the PCR-based identification of the differential gene expression (Fig. 2) is the finding that $\alpha 1$-ACT and HEF- $1 \alpha$ were preferentially expressed in PCI-06A-Raf(AS) and PCI-06A-Raf(K) transfectants, respectively. There was an approximately $170 \%$ overexpression of $\alpha 1$-ACT in PCI06A-Raf(AS) transfectants compared with that of PCI-06A-Raf(K) transfectants. An approximately $160 \%$ increase in HEF- $1 \alpha$ expression was observed in PCI-06A-Raf(K) transfectants compared with that in PCI-06A-Raf(AS) transfectants. Surprisingly, the Northern blot analysis of COX-II and OAz did not complement the differential display gel (DD-gel)-derived information. COX-II, which was initially isolated from the DD-gel based on the higher band intensity in PCI-06A-Raf(K) transfectants (KAS-103, Fig. 2), showed an approximately $190 \%$ increase in the expression in PCI-06A-Raf(AS) compared with that in PCI-06A-Raf(K) transfectants in the Northern blots (Fig. 4). Likewise, DD-gel showed the higher band intensity of OAz in PCI-06ARaf(AS) transfectants (KAS-104, Fig. 2), whereas the Northern blot analysis showed an approxi-

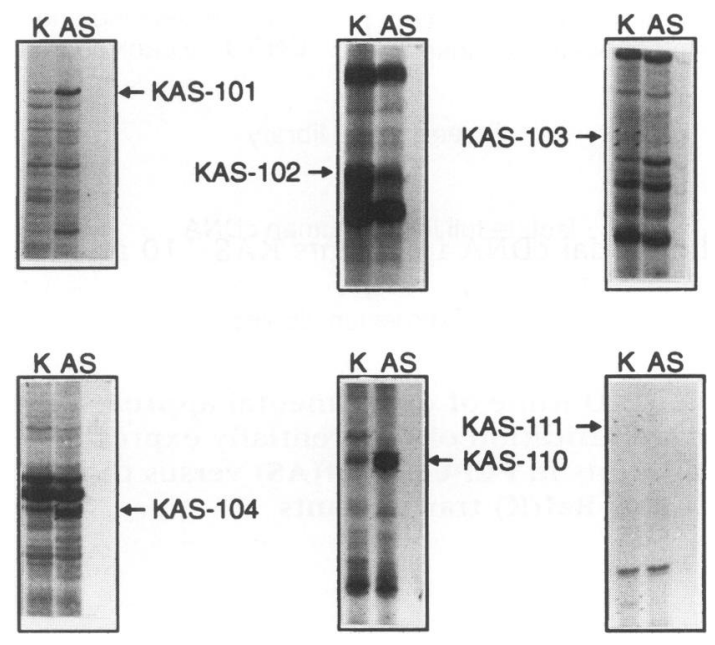

FIG. 2. Identification of differentially expressed mRNAs in PCI-06A-Raf(AS) versus those in PCI-06A-Raf(K) transfectants

The differentially expressed fragments are indicated by arrows, and they were generated in the PCR reactions using different combinations of an anchor primer and an arbitrary primer as described in Table 1. The PCR-amplified $\alpha-\left[{ }^{35}\right.$ S]dATP-labeled products were electrophoresed in $6 \%$ polyacrylamide gels, followed by autoradiography as described in Materials and Methods. AS, PCI-06A-Raf(AS); K, PCI-06A-Raf(K).

mately $201 \%$ increase in its expression in PCI06A-Raf(K) compared with that in PCI-06ARaf(AS) transfectants (Fig. 4). The possible reasons for this discrepancy between the DD-gel methodology and the Northern blot assay are 
TABLE 2. Identification of partial cDNA fragments

\begin{tabular}{|c|c|c|c|}
\hline $\begin{array}{l}\text { cDNA } \\
\text { Fragment }\end{array}$ & $\begin{array}{l}\text { DNA Database } \\
\text { (Accession No.) }\end{array}$ & Identification & Reference \\
\hline KAS-101 & GenEMBL (JO5176) & Human $\alpha$ l-antichymotrypsin & 26 \\
\hline KAS-102 & GenEMBL (JO4617) & Human elongation factor EF- $1 \alpha$ & 27 \\
\hline KAS-103 & GenEMBL (X55654) & $\begin{array}{l}\text { Human mitochondrial cytochrome c oxidase } \\
\text { subunit II }\end{array}$ & Direct submission \\
\hline KAS-104 & GenEMBL (U09202) & Human ornithine decarboxylase antizyme & 28 \\
\hline KAS-110 & GenEMBL (U70772) & Novel & This study \\
\hline KAS-111 & GenEMBL (U70771) & Novel & This study \\
\hline
\end{tabular}

discussed below. The differences observed by the Northern blot analysis of the expression of COX-II and OAz genes were found to be reproducible, and they were significant when compared using the paired $t$ test (Fig. 4).

\section{Differential Expression of Novel Genes Following Constitutive Modulation of Raf-1, and in Human Normal Tissues and Cancer Cell Lines}

The partial cDNA fragments KAS- 110 and KAS111 (Table 2, Fig. 3) were radiolabeled and hybridized to total RNA extracted from the PCI06A-Raf(AS) and PCI-06A-Raf(K) transfectants. The KAS- 110 and KAS- 111 transcripts, $\sim 0.9 \mathrm{~kb}$ and $\sim 0.5 \mathrm{~kb}$, respectively, were seen in both transfectants. Consistent with the PCR-based differential expression analysis is the finding that KAS-110 expression was higher $(\sim 200 \%)$ in PCI-06A-Raf (AS) transfectants (Fig. 5A). However, contrary to the DD-gel data, Northern blot analysis revealed an $\sim 300 \%$ increase in expression of KAS-111 gene in the PCI-06A-Raf (AS) transfectants compared with that in PCI-06A-Raf (K) transfectants (Fig. 5A). Analysis of the expression of KAS-110 and KAS-111 genes in normal human tissues indicated that, in general, KAS-111 was very well represented in a majority of the tissues, whereas KAS- 110 expression was relatively higher in heart, placenta, skeletal muscle, pancreas, prostate, testis, small intestine, and colon, compared with that in brain, lungs, liver, kidney, spleen, and ovary (Fig. 5B). Both genes were expressed in all cancer cell types examined, KAS- 110 expression being relatively abundant in a colorectal adenocarcinoma cell line (SW480), and KAS-111 gene was highly expressed in four of the eight cancer cell lines examined: chronic

\author{
KAS-110 \\ 1 tcatgggaaa agtaccgtaa atgaatggta tcggataaac aataacggga \\ 51 gttcgaggta atcccgttta acaaaaaagt aacaaaattt cagtcgtgga \\ 101 tttagaggga ccgg
}

KAS-111

1 agaccgtctt tccctgact actaaggtac tgggacgtca gcgtcttcaa

51 ggtctatcet ctaatgaacc tgtatcgtta atggggaggt ttagccogtg

101 gtggaggaag tccegcgtac tctggtataa tttaagataa atgataaaca

151 attaaataaa aaggcagtca atacatttta tttgtatgag aagaaggagg

$201 \mathrm{gg}$

FIG. 3. Partial cDNA sequences of novel transcripts differentially expressed in PCI-06ARaf(AS) versus PCI-06A-Raf(K) transfectants The nucleotide sequences representing the anchor primers (KAS-110, KAS-111; Table 1) and the arbitrary primer (KAS-111, Table 1) were confirmed as the flanking sequences (data not shown).

myelogenous leukemia (K562), colorectal adenocarcinoma (SW480), lung carcinoma (A549), and a melanoma (G361) (Fig. 5B).

\section{DISCUSSION}

The serine/threonine protein kinase Raf-1 responds to diverse stimuli and has been implicated in a number of biological responses. A global view of the molecular events following the modulation of Raf- 1 is important in the under- 

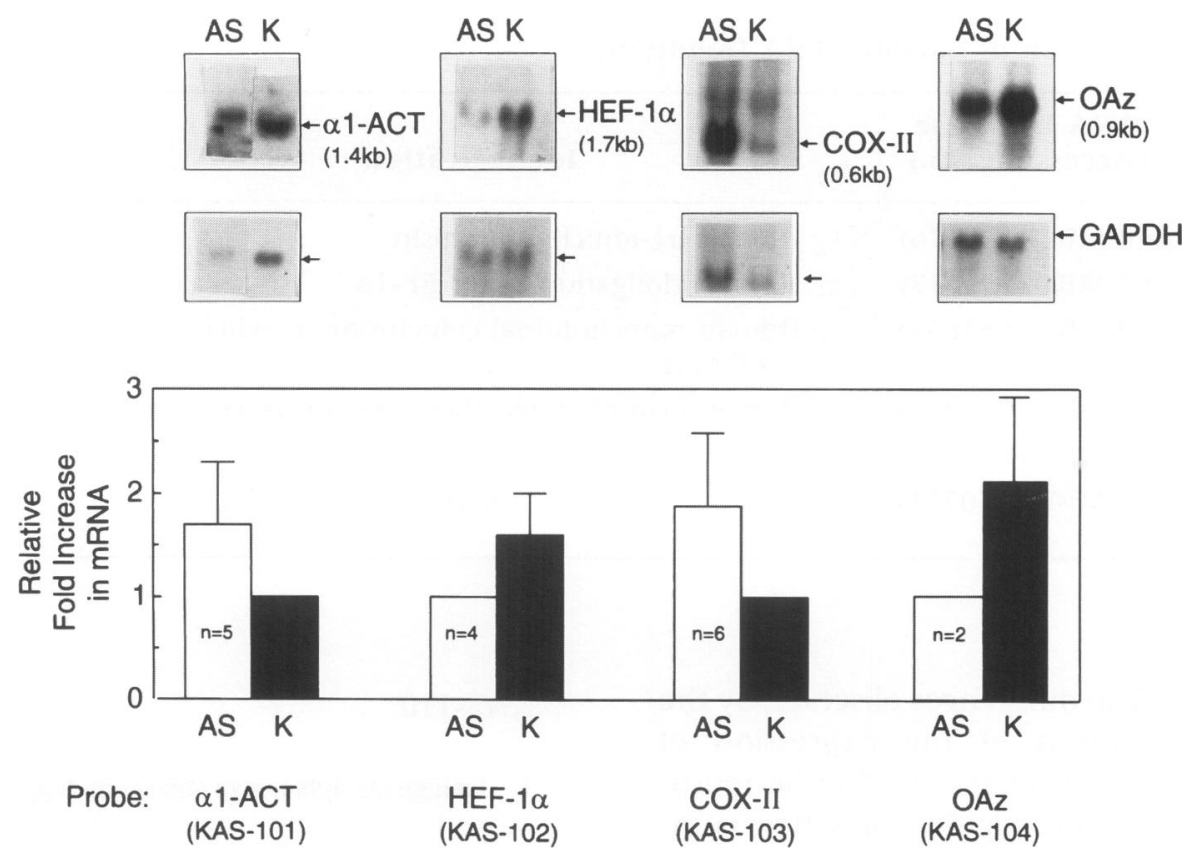

FIG. 4. Northern blot hybridization analysis of differential expression of $\alpha 1$-ACT, HEF-1 $\alpha$, COX-II, and OAz genes in PCI-06A-Raf(AS) versus PCI-06A-Raf(K) transfectants

Top panels: Northern blots were sequentially hybridized first with a radiolabeled partial human cDNA probe (KAS-101, $\alpha$ l-ACT; KAS-102, HEF- $1 \alpha$; KAS-103, COX-II; or KAS-104, OAz), followed by the radiolabeled GAPDH CDNA probe. The sizes of various transcripts are shown in parentheses. Lower panel: Computerized densitometric scanning analysis of the relative increase in gene expression. Relative fold increase in the steadystate mRNA level was calculated by first normalizing against the GAPDH signal, followed by comparison with the expression in PCI-06A-Raf(K) transfectants $(\alpha 1-\mathrm{ACT}$ and COX-II) or PCI-06A-Raf (AS) transfectants (HEF- $1 \alpha$ and $\mathrm{OAz}$ ), as explained in Materials and Methods. The data were analyzed using the paired $t$-test (Excel version 5.0), and the $p$ values for the statistical significance of the difference between the AS and the K groups were $<0.05$ ( $\alpha 1$-ACT, HEF- $1 \alpha$, COX-II). AS, PCI-06A-Raf(AS); K, PCI-06A-Raf(K).

standing of this otherwise very complex regulatory process. Our strategy to identify the components of the Raf- 1 signaling pathway was based on the premise that biological changes associated with the constitutive modification of Raf-1 protein kinase expression or activity are related to the modifications of the specific gene expression. Using well-characterized, isogeneic squamous carcinoma cells which express either the inhibited or the activated Raf- 1 protein kinase, we demonstrate that an increase in the steady-state mRNA levels of $\alpha 1-A C T$, COX-II, KAS-110, and KAS-111 correlates with the downregulation of Raf-1 protein kinase, whereas an increase in the steady-state mRNA levels of HEF- $1 \alpha$ and OAz correlates with the activation of Raf-1 protein kinase. None of these sequences has been recognized as part of the Raf-l signaling pathway thus far.

$\alpha \mathrm{l}$-ACT is a member of the serine protease inhibitor (Serpin) superfamily (29). It is primarily synthesized in the liver and is one of the acute-phase proteins that rises rapidly in response to injuries such as infections and malignancies. In certain malignant cells, $\alpha 1$-ACT has been localized to the nucleus, and it has been found to bind to DNA (29). $\alpha 1$-ACT has also been shown to exert an inhibitory effect on cell proliferation by binding to enzymes associated with DNA replication such as DNA polymerase or DNA primase. Serpins are also known to inhibit free radical production, and apoptosis by ionizing radiation $(30,31)$.

This report is not the first demonstration of a possible link between a serpin and a kinase pathway. Recently, serine protease-inhibiting drugs, tosylphenylalanine chloromethyl ketone (TPCK), and tosyllysine chloromethyl ketone (TLCK), which inhibit chymotrypsin and trypsin, have been shown to indirectly and potently inhibit activation of pp70s6k, a mitogen-regulated serine/theronine kinase involved in the Gl - to S-phase transition of the cell cycle (32). Our data 

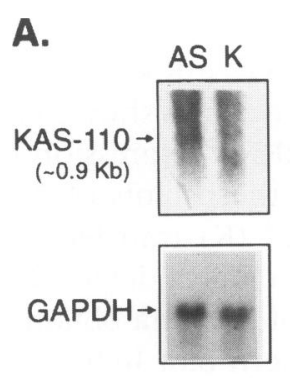
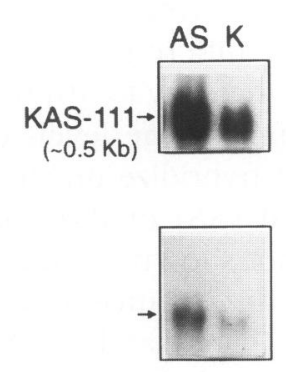

B.
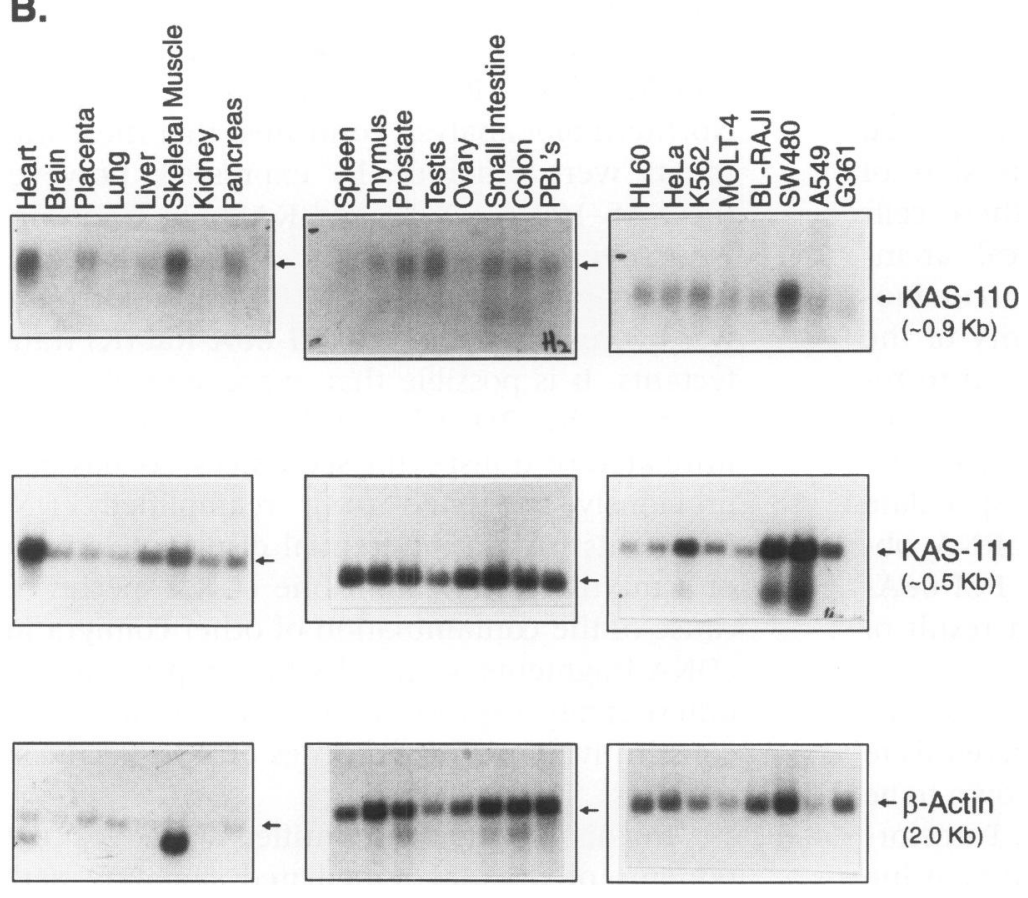

FIG. 5. Northern blot hybridization analysis of KAS-110 and KAS-111 genes

(A) KAS-110 and KAS-111 expression in PCI-06A-Raf(AS) and PCI-06A-Raf(K) transfectants. Blots were sequentially probed with KAS-110 or KAS-111 cDNA probe, followed by the GAPDH CDNA probe. (B) Comparison of the expression of KAS-110 (top panels) and KAS-111 genes (middle panels) in human normal tissues (Clontech MTN blots I and II) and human cancer cell lines (Clontech). Blots were sequentially probed with radiolabeled KAS-110, KAS-111, and $\beta$-actin (bottom panels) CDNA probes. HL-60, promyelocytic leukemia; K-562, chronic myelogenous leukemia; MOLT-4, lymphoblastic leukemia; BL-Raji, Burkitt's lymphoma; SW480, colorectal adenocarcinoma; A549, lung carcinoma; G361, melanoma.

showing an elevated expression of $\alpha 1-A C T$ in PCI-06A-Raf (AS) transfectants (Fig. 4) are in agreement with the higher expression of $\alpha \mathrm{l}$-ACT observed in the c-raf-1 knock-out mouse embryos $(-1-)$ compared with the wild-type embryos $(+I+)$ (S. Patel and U. Kasid, unpublished data). These data raise the question as to whether serine proteases are involved in a Raf-1 signaling pathway or whether there is a new role for ACT. Given a correlation between downreguation of Raf-1 expression by antisense raf cDNA or oligodeoxynucleotides and radiosensitization of squamous carcinoma cells $(17,19,20)$, increased expression of $\alpha-1$ ACT mRNA in the antisense c-raf-1 cDNA transfectants may be a protective response.

Cytochrome c oxidase is one of the electrondriven proton pumps of oxidative phosphorylation, and it plays an important role in energy metabolism (33). Induction of oxidative phosphorylation gene expression has been linked to neoplastic transformation $(34,35)$. In addition, using the differential plaque hybridization method, four mitochondrial genes, including COX-II, and the $\alpha 2$-collagen gene, have been shown to be more highly expressed in the flat revertant $\mathrm{Rl}$ cell line than in the parental human Ha-ras oncogene transformed NIH3T3 cell line (36). It is noteworthy that Ras protein is an important upstream regulator of the Raf- 1 signaling pathway and that changes in the mitochondrial gene expression are likely to reflect alterations in energy metabolism. Our observation of an increased expression of COX-II gene in the PCI06A-Raf(AS) transfectants compared with that in PCI-06A-Raf (K) transfectants (Fig. 4) suggest that COX-II is likely to be a downstream component of a Ras-Raf signaling pathway, and the 
COX-II gene may be related to an altered energy metabolism and/or the flat morphology of the PCI-06A-Raf(AS) transfectants.

Elongation factor- $1 \alpha(E F-1 \alpha)$ is a subunit of $\mathrm{EF}-1$, a $\mathrm{G}$ protein involved in mediating the binding of aminoacyl tRNAs to the $80 \mathrm{~S}$ ribosomes during RNA translation (37). The EF- $1 \alpha$ subunit binds GTP, and the exchange of GDP for GTP leads to an increase in the affinity of EF-1 for aminoacyl tRNA. Expression of HEF- $1 \alpha$ mRNA is enhanced in human cell lines transformed with various oncogenes $(38,39)$. Using differential hybridization, rat EF- $1 \alpha$ was shown to be overexpressed in a highly metastatic $\mathrm{v}$-fos transferred cell line (38). In addition, overexpression of EF- $1 \alpha$ in human fibroblasts renders these cells susceptible to transformation by chemical carcinogens, suggesting a role of HEF- $1 \alpha$ in carcinogenesis (40). Since DNA binding activity of the transcription factor AP-1 has been shown to require the activated Raf-l protein kinase (14), and the promoter region of the HEF- $1 \alpha$ gene contains the AP-1 binding site (41), we speculate that an increased level of HEF- $1 \alpha$ mRNA observed in the highly transformed PCI-06A$\operatorname{Raf}(\mathrm{K})$ transfectants (Fig. 4) may be a result of the AP-1 activity.

Ornithine decarboxylase (ODC), the key enzyme in polyamine biosynthesis, is a prerequisite for cell proliferation, and it has been shown to be critical for cell transformation (42-44). Transformation by ODC is reversed by protein tyrosine kinase inhibitors, which suggests that at least one protein tyrosine kinase downstream of ODC is important in cell transformation (45). ODC overexpression has also been shown to confer anchorage-independent growth and stimulate MAPK in human breast epithelial cells (46). Increased cellular polyamines downregulate ODC activity via induction of OAz (47). OAz overexpression in the transformed PCI-06A-Raf (K) transfectants (Fig. 4) may reflect its role in the negative feedback regulation of ODC activity in these cells.

The two as-yet unidentified genes, KAS-111 and KAS-112, were preferentially expressed in the PCI-06A-Raf (AS) transfectants, which suggests that these molecules are novel effectors of the Raf-1 pathway (Fig. 5). Their expression in multiple tissues and cancer cell lines indicates their possible housekeeping function. The isolation of their full-length cDNAs is necessary to assess the biological significance of these genes in PCI-06A cells.

We have found a high rate of 'false-posi- tives', as originally 52 bands were isolated on the basis of differentially displayed mRNAs. However, a majority $(>40)$ of these clones showed no difference in the levels of mRNA expression or did not hybridize on the Northern blots of PCI06A-Raf (AS) or PCI-06A-Raf (K) transfectants (data not shown). Another technical default has been a discordance in some of the data obtained by the DD gel and the Northern blot hybridization methods. KAS-103, KAS-104, and KAS-111 fragments did not show overexpression in the PCI-06A-Raf (K), PCI-06A-Raf (AS), and PCI06A-Raf (K) RNAs, respectively. Repeated Northern blot analysis confirmed that these fragments were differentially expressed; however, the KAS-103 (COX-II) and KAS-111 transcripts were overexpressed in the PCI-06A-Raf (AS) transfectants and the KAS-104 transcript (OAz) was overexpressed in the PCI-06A-Raf (K) transfectants. It is possible that expression of a fragment in the DD gel may be masked by other unrelated or nonspecific sequences. As has been previously suggested (48), reamplified cDNA fragments from a differential display gel consist of a mixture rather than one cDNA species because of the contamination of other comigrating cDNA fragments, some of which represent truly differentially expressed genes and others being constitutively expressed genes or nonspecific sequences.

In this report, we identified six novel components of the Raf-1-mediated signaling pathway. While the precise mechanism of induction of the specific gene expression remains to be studied, these data suggest that modulation of Raf-1 leads to interference with the transcription, processing, and/or stability of several mRNAs, resulting in the differential expression of multiple factors. Identification of these distinct effectors also implies that Raf-1 may function via multiple pathways, which could be selectively utilized in different cell types.

\section{ACKNOWLEDGMENTS}

We thank Dr. J. Richert for access to the Perkin Elmer Thermal Cycler in his laboratory, and Dr. Don Massaro for the ImageQuant software program for densitometry. This work was supported by the National Institutes of Health grants CA58984 and CA68322/OD68322 (U.K.), and NIH program project grant CA74175. Automated DNA sequencing was performed at the Macromolecular Synthesis and Sequencing Core facil- 
ity of the Lombardi Cancer Center supported by NIH grant P30-CA51008.

\section{REFERENCES}

1. Heidecker G, Kolch W, Morrison D, Rapp UR. (1992) The role of Raf-1 phosphorylation in signal transduction. Adv. Cancer Res. 58: $53-73$.

2. Devary Y, Gottlieb RA, Smeal T, Karin M. (1992) The mammalian ultraviolet response is triggered by activation of Src tyrosine kinases. Cell 71: 1081-1091.

3. Howe LR, Leevers SJ, Gomez N, Nakielny S, Cohen P, Marshall CJ. (1992) Activation of the MAP kinase pathway by the protein kinase Raf. Cell 71: 335-342.

4. Dent P, Haser W, Haystead TAG, Vincent LA, Roberts TM, Sturgill TW. (1992) Activation of mitogen-activated protein kinase kinase by v-Raf in NIH 3 T3 cells and in vitro. Science 257: 1404-1407.

5. Finco T, Baldwin A. (1993) $\kappa$ B site-dependent induction of gene expression by diverse inducers of nuclear factor $\kappa \mathrm{B}$ requires Raf- 1 . J. Biol. Chem. 268: 17676-17679.

6. Marshall CJ. (1995) Specificity of receptor tyrosine kinase signaling: transient versus sustained extracellular signal-regulated kinase activation. Cell 80: 179-185.

7. Kasid U, Suy S, Dent P, Ray S, Whiteside TLW, Sturgill T. (1996) Raf activation by ionizing radiation. Nature 382: 813-816.

8. Suy S, Anderson WB, Dent P, Chang E, Kasid U. (1997) Association of Grb2 with Sos and Ras with Raf-1 upon gamma irradiation of breast cancer cells. Oncogene 15: 53-61.

9. Stanton VP, Nichols DW, Laudano AP, Cooper GM. (1989) Definition of the human raf amino-terminal regulatory region by deletion mutagenesis. Mol. Cell. Biol. 9: 639-647.

10. Heidecker G, Huleihel M, Cleveland JL, et al. (1990) Mutational activation of c-raf-1 and definition of the minimal transforming sequence. Mol. Cell. Biol. 10: 2503-2512.

11. Kasid U, Pfeifer A, Weichselbaum RR, Dritschilo A, Mark GE. (1987) The raf oncogene is associated with a radiation-resistant human laryngeal cancer. Science 237: 10391041.

12. Patel B, Ray S, Whiteside TLW, Kasid U. (1997) Constitutive activation of Raf-1 correlates with morphological transformation and abrogation of tyrosine phosphorylation of distinct sets of proteins in human squamous carcinoma cells. Mol. Carcinog. 18: 1-6.

13. Kyriakis JM, App H, Zhang XF, et al. (1992) Raf- 1 activates MAP kinase-kinase. Nature 358: 417-421.

14. Bruder JT, Heidecker G, Rapp UR. (1992) Serum-, TPA-, and Ras-induced expression from AP-1/Ets-driven promoters requires Raf-1 kinase. Genes Dev. 6: 545-556.

15. Qureshi SA, Rim M, Bruder JT, et al. (1991) An inhibitory mutant of c-raf- 1 blocks v-srcinduced activation of the egr-l promoter. J. Biol. Chem. 266: 20594-20597.

16. Shengfeng Li, Sedivy JM. (1993) Raf-1 protein kinase activates the NF- $\kappa \mathrm{B}$ transcription factor by dissociating the cytoplasmic NF$\kappa \mathrm{B}-\mathrm{I} \kappa \mathrm{B}$ complex. Proc. Natl. Acad. Sci. USA 90: 9247-9251.

17. Kasid U, Pfeifer A, Brennan T, Beckett $M$, Weichselbaum RR, Dritschilo A, Mark G. (1989) Effect of antisense c-raf-1 on tumorigenicity and radiation sensitivity of a human squamous carcinoma. Science 243: 1354-1356.

18. Monia B, Johnston JF, Geiger T, Muller M, Fabbro D. (1996) Antitumor activity of a phosphorothioate antisense oligodeoxynucleotide targeted against c-raf kinase. Nature Med. 2: 668-675.

19. Soldatenkov VA, Dritschilo A, Wang F-H, Olah Z, Anderson WB, Kasid U. (1997) Inhibition of Raf-1 protein kinase by antisense phosphorothioate oligodeoxynucleotide is associated with sensitization of human laryngeal squamous carcinoma cells to gamma radiation. Cancer J. Sci. Am. 3: 13-20.

20. Gokhale PC, Soldatenkov V, Wang F-H, Rahman A, Dritschilo A, Kasid U. (1997) Antisense raf oligodeoxyribonucleotide is protected by liposomal encapsulation and inhibits Raf- 1 protein expression in vitro and in vivo: Implication for gene therapy of radioresistant cancer. Gene Therapy In press.

21. Wang HG, Rapp UR, Reed JC. (1996) Bcl-2 targets the protein kinase Raf-1 to mitochondria. Cell 87: 629-638.

22. Liang $P$, Pardee AB. (1992) Differential display of eukaryotic mRNA by means of the polymerase chain reaction. Science 257: $967-$ 971.

23. Patel S, Wang F-H, Whiteside TL, Kasid U. (1997) Identification of seven differentially displayed transcripts in human primary and matched metastatic head and neck squamous carcinoma cell lines: Implications in 
metastasis and/or radiation response. Eur $J$ Cancer B Oral Oncol. 33: 197-203.

24. Heo DS, Synderman C, Gollin SM, et al. (1989) Biology, cytogenetics, and sensitivity to immunological effector cells of new head and neck squamous cell carcinoma lines. Cancer Res. 49: 5167-5175.

25. Maniatis T, Fritsch EF, Aambroook J. Molecular Cloning: A Laboratory Manual. Cold Spring Harbor Laboratory Press, Cold Spring Harbor, NY, 1982.

26. Rubin $\mathrm{H}$, Wang Z-M, Nickbarg EB, et al. (1990) Cloning, expression, purification and biological activity of recombinant native and variant human $\alpha$ l-antichymotrypsins. J. Biol. Chem. 265: 1199-1207.

27. Uetsuki $T$, Naito A, Nagata S, Kaziro Y. (1989) Isolation and characterization of the human chromosomal gene for polypeptide chain elongation factor-1 $\alpha$. J. Biol. Chem. 264: 5791-5798.

28. Tewari ST, Qian Y, Thornton RD, et al. (1994) Molecular cloning and sequencing of a human cDNA encoding ornithine decarboxylase antizyme. Bichim. Biophys. Acta 1209: 293-295.

29. Rubin H. (1992) The biology and biochemistry of antichymotrypsin and its potential role as a therapeutic agent. Biol. Chem. HoppeSeyler 373: 497-502.

30. Lotem J, Sachs L. (1996) Differential suppression by protease inhibitors and cytokines of apoptosis induced by wild-type p53 and cytotoxic agents. Proc. Natl. Acad. Sci. USA 93: 12507-12512.

31. Rubin H. (1996) Serine protease inhibitors (SERPINS) Where mechanism meets medicine. Nature Med. 2: 632-633.

32. Grammar TC, Blenis J. (1996) The serine protease inhibitors, tosylphenylalanine chloromethyl ketone and tosyllysine chloromethyl ketone, potently inhibit pp70 ${ }^{\mathrm{s} 6 \mathrm{k}}$ activation. J. Biol. Chem. 39: 23650-23652.

33. Stryer L. (1995) Biochemistry. W.H. Freeman, New York.

34. Torroni A, Stepien G, Hodge JA, Wallace DC. (1990) Neoplastic transformation is associated with coordinate induction of nuclear and cytoplasmic oxidative phosphorylation genes. J. Biol. Chem. 265: 20589-20593.

35. Wang F-L, Wang Y, Wong W-K, Liu Y, Addivinola FJ, Liang P, Chen LB, Kantoff PW, Pardee AB. (1996) Two differentially expressed genes in normal and human prostate tissue and in carcinoma. Cancer Res. 56: 3634-3637.

36. Mullauer L, Suzuki H, Fujita M, Katabami M, Kuzumaki N. (1991) Identification of genes that exhibit increased expression after flat reversion of NIH/3T3 cells transformed by human activated Ha-ras oncogene. Cancer Lett. 59: 37-43.

37. Kumazawa Y, Schwartzbach CJ, Liao HX, et al. (1991) Interactions of bovine mitochondrial phenylalanyl-tRNA with ribosomes and elongation factors from mitochondria and bacteria. Biochim. Biophys. Acta 1090: 167172.

38. Taniguchi S, Miyamoto S, Sadano H, Kobayashi H. (1991) Rat elongation factor $1 \alpha$ : Sequence of cDNA from a highly metastatic fos-transferred cell line. Nucl. Acids Res. 19: 6949.

39. Koch I, Hofschneider PH, Lottspeich F, Eckerskorn C, Koshy R. (1990) Tumor-related expression of a translation-elongation factor-like protein. Oncogene 5: 839-843.

40. Tatsuka $M$, Mitsui $H$, Wada $M$, Nagata A, Nojima H, Okayama H. (1992) Elongation factor- $1 \alpha$ gene determines susceptibility to transformation. Nature 359: 333-336.

41. Wakabayashi-Ito N, Nagata S. (1994) Characterization of the regulatory elements in the promoter of the human elongation factor- $1 \alpha$ gene. J. Biol. Chem. 269: 2983129837.

42. Heller JS, Fong WF, Canellakis ES. (1976) Induction of a protein inhibitor to ornithine decarboxylase by the end products of its reaction. Proc. Natl. Acad. Sci. USA 73: 18581862.

43. Heby O, Persson L. (1990) Molecular genetics of polyamine synthesis in eukaryotic cells. Trends Biochem. Sci. 15: 153-158.

44. Auvinen M, Paasinen A, Andersson LC, Holtta E. (1992) Ornithine decarboxylase activity is critical for cell transformation. $\mathrm{Na}$ ture 360: 355-358.

45. Auvinen $M$, Paasinen-Sohns A, Hirai H, Andersson LC, Holtta E. (1995) Ornithine decarboxylase and ras induced cell transformations: Reversal by protein tyrosine kinase inhibitors and role of pp130CAS. Mol. Cell Biol. 15: 6513-6525.

46. Manni A, Wechter R, Gilmour S, Verderame MF, Mauger D, Demers LM. (1997) Ornithine decarboxylase overexpression stimulates mitogen-activated protein kinase and anchorage-independent growth of human 
breast epithelial cells. Int. J. Cancer 70: 175182.

47. Murakami Y, Matsufuji S, Miyazaki Y, Hayashi SI. (1994) Forced expression of antizyme abolishes ornithine decarboxylase activity, suppresses cellular levels of polyamines and inhibits cell growth. Biochem. J. 304: 183187.

48. Zhang H, Zhang R, Liang P. (1996) Differential screening of gene expression difference enriched by differential display. Nucl. Acids Res. 24: 2454-2455.

Communicated by A. B. Pardee. Accepted August 1 1, 1997. 